\title{
Pääministerin nousu kriisijohtajaksi
}

Koronakriisi on ensimmäinen vakava kriisi toisen maailmansodan jälkeen, jolloin turvauduttiin poikkeusolojen lainsäädäntöön. Vuonna 2011 säädetyn valmiuslain $6 \$ 1$ momentin $(1552 / 2011)$ mukaan päätöksen poikkeusoloihin siirtymisestä tekee valtioneuvosto yhteistoiminnassa tasavallan presidentin kanssa. Lain mukaan varautumista johtaa ja valvoo valtioneuvosto ja kukin ministeriö toimialallaan. Vanhan valmiuslain mukaan päätösvalta asiasta kuului presidentille (Buure-Hägglund 2002). Päätösvallan siirtäminen presidentiltä valtioneuvostolle perustuu 1980-luvulla käynnistettyyn valtiosäännön parlamentarisointiin, presidentin valtaoikeuksien supistamiseen ja pääministerin aseman vahvistamiseen.

Koronakriisin johtaminen on julkisuudessa henkilöitynyt ennen kaikkea pääministeri Sanna Mariniin. Marin ei ole pelkästään hallituksen johtaja vaan toimii niin sanottuna toimivaltaisena ministerinä, sillä valtioneuvoston kanslia vastaa valmiuslain 6 §:ssä tarkoitetun poikkeusolojen toteamisen ja käyttöönottoasetuksen antamisen yleisestä yhteensovittamisesta. Covid-19pandemian torjuntaa puolestaan hoidetaan tartuntatautilain mukaisesti ja vastuu siitä kuuluu sosiaali- ja terveysministeriölle. Valmiuslain käyttöönoton yhteydessä julkisuuteen tuli esille riitaa johtajuudesta presidentti Niinistön ja pääministeri Marinin välillä.

Tässä kirjoituksessa analysoin pääministerin roolin kehitystä kriisijohtajaksi uuden perustuslain aikana. Teemaa on tutkittu varsin vähän, eikä se nouse esille pääministerin aseman vahvistumista käsittelevissä tutkimuksissa (Jyränki 2000, 129-131, 134-145, 147, 204, 208, 210; Myllymäki 2010; Paloheimo 2001; 2003, 2005, ks. kuitenkin ulkopolitiikan osalta Raunio ja Wiberg 2001, 51-86; Raunio 2012, 567-584). Vuoden 2020 koronakriisin hoito paljastaa uuden ulottuvuuden pääministerin toimivallassa: valmiuslaki (1552/2011) ja laki valtioneuvoston tilannekeskuksesta (300/2017) luovat pääministerille uudenlaista roolia kriisijohtajana.

Kytken pääministerin aseman kriisijohtajana yhtäältä poliittisen vallan sisäisiin kilpa-asetelmiin pääministerin ja presidentin välillä ja toisaalta suomalaisen hallitusmallin - kollegiaalinen hallitusmalli, ministeriömalli ja pääministerijohtoinen malli - muutostrendeihin. 2000-luvulla perinteinen kilpailu kollegiaalisen mallin ja ministeriömallin välillä on hävinnyt muuntuen ministeriömallin ja pääministerijohtoisen mallin kilpailuksi (Murto 1994; Myllymäki 2010, 179190, 247-324; Nousiainen 1999, 1102-1111). Sijoitan pääministerin kriisijohtajuuden näiden kahden erilaisen ja eritasoisen kilpa-asetelman kenttään.

Pääministerin asemaa täsmentävien säännösten ottaminen perustuslakiin ja presidentin valtaoikeuksien supistaminen ovat vahvistaneet pääministerin asemaa toimeenpanovallan johtajana. Säädösmuutosten ohella pääministerin asemaa ovat muokanneet poliittiset käytännöt ja niistä tehtävät tulkinnat (Hallberg ym. 2009, 320-367; Karvonen ym. 2016, 9-30; Raunio ja Wiberg 2003, 301-324; Raunio 2016, 231-238). Suomalaisen poliittisen tradition voiman vaikutuksesta presidentillä on edelleen vahva asema valtiollisena johtajana. Monien 2000luvun pääministerien lyhyet urat ja presidenttejä vähäisempi poliittinen kokemus vaikuttavat 
pääministerin asemaan valtiollisena johtajana. Keskityn tässä esityksessä pääministerin asemaan kriisijohtajana. Koska asiaa ei ole säädelty perustuslaissa, pääministerin kriisijohtajuus riippuu valtiollisen johtamisen yleisestä lainsäädännöstä ja poliittisten käytäntöjen kehityksestä (Forsberg 2001, 3-11).

\section{KRIISIJOHTAMISEN KIVINEN TIE PÄÄMINISTERIN TEHTÄVÄKSI}

Vuoden 2001 terrori-isku Yhdysvaltoihin ja sen jälkeen tehdyt terrori-iskut eri maihin ovat nostaneet kriiseihin varautumisen aiempaa vahvemmin esille myös Suomessa (Forsberg ym. 2003). Suomessa erityisesti Thaimaan tsunami-onnettomuus vuonna 2004 vauhditti toimenpiteitä (Volanen 2011, 79-80). Kriisijohtaminen on kehittynyt pääministerin ja hänen johtamansa valtioneuvoston kanslian tehtäväksi 2000-luvulla pienin askelin hallitusten päätösten, hallinnollisten ja poliittisten käytäntöjen sekä viime vuosina myös lakien ja asetusten kautta.

Merkittävä virstanpylväs valtioneuvoston kanslian roolin kehityksessä kriiseihin varautumisen alalla on Vanhasen I hallituksen periaatepäätös Yhteiskunnan elintärkeiden toimintojen turvaamisen strategian (YETT) tarkistamisesta marraskuulta 2003. YETT määrittelee vastuun valtiojohdon toimintaedellytysten yhteensovittamisesta ja siviilikriisien johtamisesta - nykytermein kriisihallinnasta - valtioneuvoston kanslialle. Tehtävän - käytännössä tilannekuvan - hoitaminen määrättiin valtioneuvoston kanslian turvallisuuspäällikölle, jonka puolustusvoimat oli pääministerin pyynnöstä jo aiemmin komentanut tehtävään. Valtioneuvoston kanslian tuli käsitellä yhteistoiminnassa muiden ministeriöiden kanssa ne asiat, jotka liittyivät valtioneuvoston ja ministeriöiden turvallisuuspalveluun sekä häiriötilanteisiin ja poikkeusoloihin varautumiseen. (Asetus valtioneuvoston kansliasta 459/2003, 1 \$; Valtioneuvoston periaatepäätös 2003.)

Yhteiskunnan elintärkeiden toimintojen strategia joutui käytännön testiin joulukuussa 2004, kun Intian valtameren maanjäristyksen synnyttämät valtavat hyökyaallot aiheuttivat tsunamin, jonka kohteeksi Thaimaassa joutui noin 3000 suomalaista. Heidät oli siirrettävä kotimaahan. Tuolloin voimassa ollut toimivaltaisen ministeriön vastuuseen perustunut johtamismalli ei toiminut riittävän ripeästi, mistä syystä pääministeri valtuutti valtiosihteerinsä toimimaan koordinaattorina (Volanen 2011, 19-98). Tsunamin käsittely paljasti valtioneuvoston kriisijohtamisen puutteita kriisijohtamisen säädöspohjassa, kriisien johtamisen instituutioissa ja valtiojohdon tilannekuvajärjestelmässä (Onnettomuuskeskus 2004, 40-45, 142-144; Volanen 2011, 19-98).

Tsunami-operaatiota selvittänyt Martti Ahtisaaren johtama ryhmä totesi toukokuussa 2005, että valtioneuvoston kanslian tilannekeskuksesta tulisi muodostaa jatkuvasti toimintakykyinen johtamisväline ja huolehtia tilannekuvan poikkihallinnollisesta luonteesta. Lisäksi tulisi luoda menettely toimivan johto- ja koordinaatioyksikön muodostamiseksi. Työryhmä piti kiinni valtionhallinnon toiminnan johtamisesta normaaliorganisaatiolla mahdollisimman pitkään myös poikkeustilanteissa (Onnettomuuskeskus 2004, 153). Tilannekeskuksen sijoittamista valtioneuvoston kansliaan perusteltiin pääministerin tarpeella erityisesti kriisi- ja häiriötilanteissa ottaa nopeasti kantaa ja tehdä päätöksiä valtioneuvoston johtamisesta ja vastuunjaosta. Pääministeri kantaa vastuun hallituksen toimintakyvystä. Tilannekeskuksen juridisena perustana pidettiin perustuslain pääministerille määrittämää vahvaa asemaa valtioneuvoston johtajana sekä asioiden valmistelun ja käsittelyn yhteensovittajana. 


\section{KRIISIJOHTAMISEN JOHTOVASTUIDEN MÄÄRITTELY}

Vanhasen hallitus I määritti marraskuussa 2006 tekemässään päivitetyssä Yhteiskunnan elintärkeiden toimintojen turvaamisen strategiassa valtion kriisijohtamismallin. Se on ensimmäinen selkeä tahdonilmaisu Suomen kriisijohtamisesta. Mallin mukaan valtioneuvostolla ja valtioneuvoston kanslialla on kriisissä johtava asema. Siinä tarkoituksessa kansliassa valmisteltiin erillisen siviilikriisien johtamista tukevan ja valtioneuvoston kansliassa toimivan valtioneuvoston johtokeskuksen perustamista (Valtioneuvoston periaatepäätös 2006, 26; Volanen 2007, 37).

Valtioneuvoston kanslian aktivoituminen herätti epäilyksiä monissa ministeriöissä. Valtioneuvoston kanslia jatkoi epäilyksistä huolimatta tilannekeskuksen ja johtamisjärjestelmän rakentamista. Huhtikuussa 2007 annetussa valtioneuvoston asetuksessa valtioneuvoston kansliasta (393/2007) kanslian tehtäviä kriisijohtamisessa täsmennettiin. Asetuksen 1 §:n 24 kohdan mukaan valtioneuvoston kanslialle kuuluvat valtioneuvoston turvallisuuspalvelut, turvallisuuteen liittyvän yleisen tilannekuvan kokoaminen ja valtioneuvoston yhteinen poikkeusoloihin varautuminen. Syyskuussa 2007 valtioneuvoston kansliaan perustettiin vuorokauden ympäri toimiva tilannekeskus ja valmiusosasto (Saari 2012, 9).

Vanhasen II hallituksen tekemä päätös siviilikriisien johtamismallista joutui uudelleenarvioitavaksi Kiviniemen ja Kataisen hallitusten aikana. Kiviniemen hallitus uskoi siviilikriisihallinnan valmistelun johdon puolustusministeriölle ja puolustusministeriön yhteydessä toimineelle Turvallisuus- ja puolustusasiain komitealle. Linjamuutos kirjattiin Kiviniemen hallituksen 2010 hyväksymään Yhteiskunnan turvallisuusstrategiaan. Siinä korostetaan sektoriviranomaisten ja -ministeriöiden johtovastuuta. Pääministeri ja valtioneuvoston kanslia tulevat mukaan vasta myöhemmin kriisin pitkittyessä. Viranomaisten vastuujako ja yhteistyöelimien toimintamallit säilytetään mahdollisimman pitkään normaaliolojen mukaisina. (Valtionneuvoston periaatepäätös 2010.)

Kiviniemen hallituksen päätös ei lopettanut johtamismallia koskevaa kiistaa valtioneuvostossa. Asiaa ryhdyttiin selvittämään erityisessä komiteassa, joka piti valtioneuvoston kanslian vastuulle luotua kriisijohtamisen järjestelmää hajanaisena. Ongelmien korjaamiseksi komitea esitti tilannekuvatoiminnan siirtämistä puolustusministeriöön perustettavalle turvallisuuskomitealle (Valtioneuvoston kanslia 2010, 83-84). Asian ratkaisu siirtyi Kataisen hallitukselle, joka joulukuussa 2012 hyväksymässään Kokonaisturvallisuusohjelmassa päätyi myös toimivaltaisen ministeriön mallin kannalle ja kokonaisuuden koordinaation kokoamista puolustusministeriön päävastuulle (Valtioneuvoston periaatepäätös 2012, 7; Volanen 2011, 76-96). Kataisen hallituksen kriisijohtamisen malli perustui hajautetun vastuun pohjalle.

Kokonaisturvallisuusohjelman esityksen mukaisesti puolustusministeriön yhteyteen perustettiin Turvallisuuskomitea avustamaan valtioneuvostoa ja sen ministeriöitä kokonaisturvallisuuden hallintaan tähtäävässä ennakoivassa varautumisessa ja varautumisen yhteensovittamisessa. Turvallisuuskomitean tehtävä ei ole häiriö-, kriisi- tai poikkeustilanteen johtaminen tai toiminnan ohjaaminen. Toimivaltaiset viranomaiset vastaavat varautumisesta ja toiminnan ohjaamisesta omalla hallinnonalallaan. (Valtioneuvoston periaatepäätös 2012, 6, 11-12.) Turvallisuuskomitealle määriteltiin vastuu turvallisuuskysymysten varautumisen ylimmän tason koordinaatiosta valtionhallinnossa. Valtioneuvoston kanslia vastaa häiriötilanteiden hallinnan yleisestä yhteensovittamisesta valtioneuvostossa. 
Valtioneuvoston kanslian roolia kriisijohtamisessa täsmennettiin vuonna 2015 määräämällä valtioneuvoston kanslian tehtäväksi yhteinen tilannekuva, varautuminen ja turvallisuus sekä häiriötilanteiden hallinnan yleinen yhteensovittaminen (Valtioneuvoston kanslia 2015). Vuonna 2016 tilannekeskuksesta annettiin laki (300/2017) ja valtioneuvoston kanslialle määrättiin vastuu valmiuslain 6 §:ssä tarkoitetun poikkeusolojen toteamisen ja käyttöönottoasetuksen antamisen yleisestä yhteensovittamisesta (Valtioneuvoston ohjesääntö 333/2017, $12 \S 7$. kohta). Annetut säädökset lisäsivät valtioneuvoston kanslian ja pääministerin vastuuta kriisijohtamisessa.

Tilannekeskuksesta annettiin lakitasoinen säädös vasta pääministeri Juha Sipilän hallituksen aikana 2017. Tilannekuvatoiminnan tavoitteena on lain mukaan tukea presidentin ja valtioneuvosto päätöksentekoa siten, että valtion itsenäisyyteen, väestön elinmahdollisuuksiin ja muihin yhteiskunnan elintärkeisiin toimintoihin kohdistuvat uhkat ovat hallittavissa (HE 261/2016 vp, 18). Tilannekeskuksen sijoittaminen valtioneuvoston kansliaan perustui Vanhasen hallituksen omaksumaan pääministerivetoiseen kriisijohtajuusmalliin (Volanen 2016, 463-486). Pääministeri Sipilän hallitus otti kantaa kriisijohtamisen malliin vuonna 2017 hyväksymässään Yhteiskunnan turvallisuusstrategiassa. Kriisijohtamisen mallia vodaan pitää kompromissina toimivaltaisten ministeriömallin ja pääministerijohtoisen valtioneuvostomallin välillä (Valtioneuvoston periaatepäätös $2017,16,31)$.

\section{PÄÄMINISTERIN KRIISIJOHTAJUUDEN VAIKEUS}

Sipilän hallituksen linjaukset ja niiden mukaisesti tehdyt päätökset eivät muuttaneet vakiintunutta kokonaisturvallisuuden johtojärjestelmää, jonka muut osat ovat 1) puolustusministeriön toimialaan kuuluva kokonaismaanpuolustuksen yhteensovittaminen (Valtioneuvoston ohjesääntö 262/2003, $6 \$ 3$. kohta, 2) puolustusministeriön yhteydessä toimivan Turvallisuuskomitean vastaama kokonaisturvallisuuden ja häiriötilanteiden koordinointi (Valtioneuvoston asetus Turvallisuuskomiteasta 77/2013) ja 3) sisäasiainministeriön vastaama aluehallinnon poikkeusoloihin ja häiriötilanteisiin varautuminen (Kivelä 2016, 61-187; Valtioneuvoston ohjesääntö 1445/2024, $15 \$ 8$. kohta).

Pääministerin kriisijohtamisen luonnetta arvioitaessa on muistettava, että pääministerin aseman vahvistuminen 2000-luvulla on ollut pääosin poliittista ja koskenut valtioneuvoston käytännön työskentelyä. Pääministerin poliittisen aseman vahvistaminen ei ole muuttanut valtioneuvoston vanhan kollegiaalisen ja sitä 1990-luvulla ministeriömallin suuntaan uudistetun aiempaa hajautuneemman johtamisjärjestelmän perustaa: valtioneuvostolle kuuluvat asiat ratkaistaan edelleen oikeudellisesti sitovalla tavalla joko valtioneuvoston yleisistunnossa tai asianomaisessa ministeriössä (Paloheimo 2016, 75-78). Pääministerille ei ole uskottu valtioneuvoston oikeudellisesti sitovan päätöksenteon sisältöön suoranaisesti liittyvää valtaa.

Sipilän hallitus yritti vahvistaa pääministerin asemaa myös valtioneuvoston johtamista ja päätöksentekoa koskevilla säädösmuutoksilla. Pääministeri puhui usein yhtenäisestä valtioneuvostosta ja kollegiaalisuuden vahvistamisesta valtioneuvostossa, sillä valtioneuvoston päätöksenteko oli 1990-luvulta alkaen siirtynyt ministeriöille ja näin heikentänyt valtioneuvoston yhtenäisyyttä. Hallituksen asiaa selvittämään asettama Seppo Tiitisen johtama parlamentaarinen työryhmä tyrmäsi ajatuksen organisatorisesti yhtenäisestä valtioneuvostovirastosta ja pääministerin aseman 
vahvistamisesta valtioneuvoston johtamisessa (Valtiovarainministeriö 2017, 13-14, 24). Pääministerin aseman vahvistaminen kaatui jälleen kerran, yhtenäinen valtioneuvosto jäi rakentamatta ja pääministerin vallan kasvattaminen jäi vain haaveeksi.

Edellisestä voidaan tehdä selkeä päätelmä: Poliittiset päätöksentekijät kokevat valtioneuvoston johtamisen uudistamisen pääministerijohtoisen mallin suuntaan rikkovan historiallisesti muotoutuneen kollegiaalisen perinteen pohjalle rakentuneen valtioneuvostomallin. Suomalaisen mallin katsotaan toimivan kohtuullisen hyvin ja sopeutuvan suomalaiseen puoluejärjestelmän. Tutkijat esittävät kuitenkin suosituksia pääministerin aseman vahvistamisesta ja kiinnittävät huomiota Suomesta puuttuvaan vahvaan poikkihallinnolliseen johtajuuteen, strategisen kokonaisnäkemyksen ja poikkihallinnollisuuden puutteeseen (Alter 2019; Bouckaert ym. 2010; Kivelä 2010; 2016, 202-203). Lobbausta tutkineen Anders Blomin $(2018,289)$ mukaan valtioneuvoston ministeriöpohjainen ja siilomainen rakenne ja työskentelytapa ovat myös lobbausta harjoittavien etujärjestöjen intressissä. Siiloutuneessa valtioneuvostossa ne voivat kohdistaa vaikuttamispyrkimyksensä helposti ministeriöihin, virkamiehiin ja ministerien poliittisiin esikuntiin.

\section{KORONAPANDEMIA VAHVISTAA PÄÄMINISTERIN ROOLIA VALTIONEUVOSTON KRIISIJOHTAJANA}

Kiinan Wuhanissa vuoden 2019 lopulla puhjenneen koronaviruksen aiheuttaman pandemian leviäminen Suomeen on ensimmäinen testi, johon edellisessä jaksossa käsitelty kriisijohtamisen malli joutui. Koronakriisi osoitti mallin toimivuuden, mutta myös ongelmia ja sen, että pääministerin rooli perustuu pääministerin, hallituspuolueiden puheenjohtajien ja toimivaltaisen ministerin tilannekohtaiseen tulkintaan.

2010-luvulla omaksutun kriisijohtamismallin mukaisesti koronaviruksen aiheuttaman terveyskriisin torjunnan johto kuuluu sosiaali- ja terveysministeriölle (STM) ja sen alaisuudessa toimivalle Terveyden ja hyvinvoinnin laitokselle (THL). Ne ryhtyivät jo tammikuun alkupuolella rakentamaan ennusteita viruksen liikkumisesta maailmalla ja sen saapumisesta Suomeen. Valtioneuvostotasolla seuranta aloitettiin tammikuun puolivälissä (Valtioneuvoston selvityksiä 2021, 12, 14-16; Mörttinen 2021, 15). Valtioneuvoston kansliassa toimiva tilannekeskus ryhtyi tammikuun lopulla valmistamaan pääministerille, avainministereille, valtiosihteereille ja kansliapäälliköille korona-tilannekatsauksia. Pandemian poliittista hoitoa selvittäneen Matti Mörttisen $(2021,22)$ mukaan hallituksessa ei vielä helmikuun puolivälissä hallituksessa olisi tunnettu kriisitietoisuutta.

Helmikuun lopulla Marinin hallitus ryhtyi ottamaan valtioneuvostotason johtajuutta koronakriisin käsittelyssä asettamalla 26. päivä valtioneuvoston kansliaan covid-19-koordinaatioryhmän (Valtioneuvoston viestintäosasto 2020). Hallitus arvioi tuolloin, että kriisi voidaan hoitaa tartuntatautilain avulla STM:n johdolla. Tämän mukaisesti koordinaatioryhmän ulkopuolelle jätettiin muun muassa oikeusministeriön ja opetus- ja kulttuuriministeriön edustajat. Pari viikkoa aiemmin (13.2.) hallitus oli määrittänyt koronoviruksen tartuntatautilain määrittämäksi tarttuvaksi taudiksi. Samana päivänä STM (2020; ks. myös Mörttinen 2021, 42-43) oli asettanut sosiaali- ja terveydenhuollon varautumista ja johtamista tukevan varautumisen koordinaatioryhmän ja sen alaisuudessa toimivan operatiivisen ryhmän. 
Lehdistössä arvosteltiin hallituksen ja pääministerin kriisijohtamisen sekavuutta ja heikkoa kokonaisuuden johtamista. Arvostelun olisi pitänyt kohdistua omaksuttuun valtioneuvoston kriisijohtamisen malliin, jonka mukaisesti toimittiin. Mallin mukaisesti pääministeri saattoi asettua kriisin johtoon vain poliittisesti. Juridinen päästövalta ja johtajuus kuuluu sosiaali- ja terveysiministeriölle. Valtioneuvostotason hitaaseen johtajuuden ottamiseen on voinut vaikuttaa pääministeri Marinin lyhyt kokemus pääministerinä ja perhe- ja peruspalveluministeri Krista Kiurun vahva poliittinen johtajuus ja heidän keskinäiset poliittiset riippuvuutensa. Lehdistössä kiinnitettiin huomiota myös ministerien poliittisten kabinettien ja valtiosihteereiden aktiiviseen osallistumiseen kriisin johtamiseen (Haapala 2020a; Mörttinen 2021, 41-42).

Keskustelu hallituksen kriisijohtamisesta nousi uudelle tasolle presidentti Niinistön otettua asiaan kantaa maaliskuun puolivälissä. Hän esitti kansallinen turvallisuusneuvoston perustamista (Nurmi ja Ristimäki 2020). Pääministeri torjui lehdistön spekulaatiot presidentin halusta ottaa asiassa johtorooli. Marin totesi vastuun valmiuslain toimeenpanosta kuuluvan valtioneuvostolle ja että hän johtaa sitä (Vesala 2020a). Niinistön esityksen taustalla lienee ollut ensinnäkin presidentin saamat erilaiset tiedot pandemian kansainvälisestä kehityksestä ja hänen niistä tekemänsä tulkinta, toiseksi valmiuslain säännökset (Mörttinen 2021, 25) ja kolmanneksi Niinistön tietoisuus presidentti-instituution vahvasta roolista Suomen kokonaisturvallisuuden johtojärjestelmässä.

Presidentin ja pääministerin sanaharkka kiihtyi, kun julkisuuteen tuli presidentin kannanotto valtioneuvoston kansliaan perustettavasta kriisiä johtavasta "nyrkistä". Presidentti todella esitti ajatuksen erityisestä nyrkistä Marinille 26.3. osoittamassaan kirjeessä. Siinä presidentti toteaa, että paha on vasta edessä ja pahin seuraa sitä. On tehtävä kovia päätöksiä, mutta lisäksi kriisiä on johdettava operatiivisesti ja huolehdittava, että kokonaistilanne on hallittavissa. Presidentin mukaan viranomaiset virkavastuulla hoitavat kriisiä, mutta se ei riitä. "Toistan moneen kertaan esitetyn ajatuksen operatiivisen 'nyrkin' käyttämisestä. Tiiviisti käytännön asioissa työskentelevä ryhmä takaisi, että rattaat pyörivät säädettyyn tahtiin.” (Niinistö 26.3.2020; ks. myös Mörttinen 2021, 56-57; Vesala 2020b.)

Pääministeri vastasi presidentin kirjeeseen vielä samana päivänä. Marin kiistää erillisen nykyisen hallinnon ulkopuolisen kriisijohtoryhmän tarpeen. Pääministeri kiitti presidenttiä yhteistyöstä ja hänen puheenvuoroistaan kansalaisten suuntaan. Marin piti tärkeänä, että päätökset tehdään virkavastuulla valmisteltujen esitysten perusteella, ja niin, että vastuusuhteet säilyvät selkeinä. "Otan hallituksen puolesta harkintaani tekemänne ehdotuksen kriisiryhmästä", hän totesi. (Marin 30.3.2020). Presidentin ja pääministerin kirjeenvaihto viittaa valtiojohtamisen jonkinasteiseen kriisiin. Presidentti koki tarpeelliseksi ohjeiden antamisen pääministerille kriisin operatiivisesta johtamisesta. Pääministeri torjui nyrkin perustamisen toimivaltaisen ministerihallintomallin mukaisesti. Hän käytännössä totesi, että pääministeri ja valtioneuvosto eivät voi ottaa toimivaltaa sosiaali- ja terveysministeriöltä. Kirje osoittaa pääministerin pitävän presidentin ulostuloa puuttumisena valtioneuvoston asioihin. Pääministeri jatkoi Twitter-viestissään 29.3. kohteliaan ärsyyntyneesti presidentin arvostelua: "Kriisiaika ei ole se hetki, jolloin kyseenalaistetaan toimivaltaisten viranomaisten osaaminen ja kyky, tai uudistetaan johtamisen rakenteen. Kriisissä tehdään päätöksiä ja toimitaan sen tiedon pohjalta, joka on käytettävissä. Hallinnon tehtävä on toimeenpanna linjaukset." Hän lisäsi: "Yhtälailla on tärkeää pitää yllä mutkatonta vuoropuhelua instituutioiden välillä. Nähdäkseni keskusteluyhteys valtioneuvoston, 
eduskunnan ja presidentin välillä on ollut suora ja toimiva... Jotta voimme onnistua työssämme mahdollisimman hyvin, tarvitsemme myös työrauhaa." (Marin 29.3.2020.) Viestien sanoma on selkeä: pääministeri ja presidentti olivat eri linjoilla kriisin johtamisesta. Pääministeri torjui presidentin neuvot pitäen niitä sekaantumisena hänen ja hallituksen asioihin.

Myös eduskunnan puhemies Matti Vanhanen arvosteli Yleisradion Ykkösaamun haastattelussa 1.4. poikkeuksellisen jyrkkäsanaisesti presidenttiä ja tuki pääministeriä. Vanhanen ihmetteli presidentin sekaantumista terveysalan kriisin käsittelyyn. Siinä presidentillä ole roolia. "Presidentti, hallitus ja eduskunta hoitavat omat asiansa eivätkä puutu toisten tontille kuuluviin asioihin. Eduskunta ei neuvo miten presidentin kanslia organisoi työnsä eikä sitä, kuinka hallitus organisoi työnsä. Jokainen valtioelin hoitaa oman työnsä ja kantaa vastuun siitä, miten työnsä organisoi." Koronakriisin johtaminen on Vanhasen mukaan pääministerijohtoista toimintaa. Operatiivinen johtoryhmä sekoittaisi toimintaa. Päätösvalta on Vanhasen mukaan hallituksella ja eduskunnalla ja se on tarkkarajaisesti määritelty: "Jos presidentti ja hallitus ovat eri linjoilla ja eri mieltä, hallitus ratkaisee asiat eduskunnan tuella. Se on täysin selvää.” 2000-luvun alussa pääministerinä toiminut Vanhanen totesi, että organisaation tulee olla selkeästi pääministerivetoinen ja että sektoriministeriöiden ja -virastojen tulee sopeutua siihen. (Vanhanen 2020.) Vanhasen lausunto Yleisradiolle perustui hänen oman hallituksensa aiemmin omaksumaan pääministerijohtoiseen kriisin johtamismalliin ja tulkintaan pääministerin poliittisesta johtamisesta, ei pääministerin juridisesta johtajuudesta.

Presidentin kirjeen takia tai siitä riippumatta valtioneuvoston kansliaan perustettiin 1.4. pysyvän tilannekeskuksen rinnalle erillinen ja pitkälti koronavirukseen keskittyvä operaatiokeskus. Sen jäsenet olivat eri ministeriöistä ja valtioneuvoston kansliasta (Karjalainen 2020).

Koronakriisin iskiessä voimalla Suomeen kriisijohtamisen järjestelmä ei ollut vain heikko vaan myös sekava. Kokonaisuuden koordinaatiota ei ollut. Poikkihallinnollista kriisihallinnan koordinaatiota pääministerin johdolla ei ollut kehitetty. Valtioneuvoston kanslian tehtäväkenttä riskien analysoinnin ja kriisien ennakoinnin alalla on yleinen ja resurssit vähäiset. Edelliset kokemukset poikkeusoloihin joutumisesta ovat sodan ajalta ja 1990-luvun alusta (Forsberg ym. 2003, 115-206; Hellenberg ym. 2011). 2000-luvulla on ollut myös pienempiä kriisejä (Hellenberg, ym. 2011, Mörttinen 2021, 11-13, 20). Edes Yhdysvaltoihin syyskuussa 2001 tehdyn terroristi-iskun jälkeen laadituissa analyyseissä kriisijohtamisesta ei pääministerillä tai valtioneuvoston kanslialla ole katsottu olevan johtoroolia (Visuri 2003, 315-334). Pääministeri Marin oli nimitetty tehtäväänsä vasta pari kuukautta aiemmin ja myös pääministerin poliittiselta kabinetilta puuttui valtioneuvoston johtamiskokemus. Hallinnon sisältä tulleen arvion mukaan covid19-operaatiokeskuksen jäsenten kokemattomuus näkyi (Haapala 2020b).

Koronakriisin hoidon siirtymistä valtioneuvostotasoiseen ja pääministerijohtoiseen malliin hidasti 1990-luvulla omaksuttu valtioneuvoston ministeriöhallintomalli. 2010-luvulla hallinnon kehittämisessä toki puhuttiin ruotsalaisen mallin mukaisesti yhtenäisestä valtioneuvostosta, joka olisi tarkoittanut ministeriöiden mieltämistä yhtenä virastona. Suomalaisessa monipuoluehallitustraditiossa pyrkimykset yhtenäisen valtioneuvoston rakentamiseksi epäonnistuivat, sillä mikään puolue ei halua luopua "omien" ministeriöidensä itsenäisyydestä ja luovuttaa johtajuutta pääministerille (Virtanen ym. 2016). Valmiuslain käyttöönottamisen seurauksena tilanne muuttui: pääministeri Marin ja hallituspuolueiden puheenjohtajien muodostama viisikko yhdessä ministeri Kiurun kanssa nousivat selkeästi kriisin johtajiksi. Kriisiä ryhdyttiin johtamaan 
ylhäältä. Pääministeri antoi valtiojohdon kasvot kriisijohtajuudelle. Hän näytti, että hallituksen päämies johtaa kriisiä edestä ja loi uskoa kriisistä selviämiseen. Ministerit osallistuivat säännöllisesti tiedotustilaisuuksiin ja käyttivät apunaan myös asiantuntijatietoa. Tällä osoitettiin, että valtiojohto on ajan tasalla, sillä se luo turvallisuuden tunnetta.

Pääministerin ja puheenjohtajien muodostaman viisikon yhteisesiintymisen taustalla oli mitä ilmeisimminkin päätös toimia pääministerijohtoisen ja samaan aikaan kollegiaalisen hallitusmallin mukaisesti. Hallitus esiintyi vahvana ja yhtenäisenä pääministerin johtamana kollektiivina: kaikki ovat mukana, mutta pääministerin johdolla. Marinin julkinen esiintyminen synnytti mielikuvaa pääministeristä valtion operatiivisena johtajana.

Presidentti puolestaan lähestyi kansalaisia empaattisena valtionpäämiehenä, kansakunnan johtajana presidentti Kyösti Kallion tapaan. Niinistö antoi lausuntoja, kirjoitti blogia, päivitti omaa Facebook-sivustoaan ja esiintyi televisiossa, erityisesti kriisin alkuvaiheessa. Sekä presidentin että pääministerin julkista esiintymistä luonnehti tunnetilojen rauhoittelu, kansalaisten lohduttaminen, yhteisyyden rakentaminen ja kansakunnan yhteishengen luominen. Pääministerin johtajuudessa oli myös vahva strategisen ja operatiivisen johtajuuden ote. Jouduttuaan sanaharkkaan Marinin kanssa presidentti omaksui vähäisemmän roolin.

Sekä Marinin hallitus että valtioneuvoston virkamiesjohto - erityisesti STM:ssä ja THL:ssä - joutuivat valmistautumattomina johtamaan kriisiä ja luomaan toimintamallit lähes tyhjästä. Virkamiesjohto joutui äkkiseltään kertomaan päätöksentekijöille tutkimustietoon perustuvia suosituksia, joiden varmuudesta se ei voinut olla itsekään varma. Se tiesi tutkimustulosten epävarmuuden ja ristiriitaisuuden. Vaikka Marinin hallitus otti järjestämiinsä tiedostustilaisuuksiin mukaan THL:n ja STM:n asiantuntijoita ja pyrki näin luomaan uskottavuutta päätöksilleen, hallitus myönsi tekevänsä päätökset ilman varmaa tietoa. Pääministeri Marin viittasi presidentti Mauno Koiviston sanoihin "Ellemme varmuudella tiedä, kuinka tulee käymään, olettakaamme, että kaikki käy hyvin.” (Marin 29.4.2020).

\section{PÄÄMINISTERIN KRIISIJOHTAJUUS}

Pääministerin kriisijohtajan roolin arviointia ei voida rajoittaa vain valtioneuvoston sisäiseen johtamiseen ja maan sisäiseen turvallisuuteen. Samaan tapaan turvallisuusuhkia ei voida rajata Suomen ulkorajojen mukaisesti valtion sisäiseen ja ulkoiseen turvallisuuteen eikä ulkopolitiikan ja maanpuolustuksen väliseen tehtävien jakoon eikä siviilikriisinhallintaan ja sotilaallisen kriisinhallintaan. Pääministerin ja presidentin roolit kriisijohtajina limittyvät kaikissa vähääkään suuremmissa kriiseissä toisiinsa. Presidentti on johtava toimija ulko- ja turvallisuuspolitiikan alalla, ja pääministeri kantaa vastuun toimeenpanovallan kaikkien lohkojen yleisjohtajuudesta.

Koronakriisin johtamisessa olivat vastakkain valtioneuvoston kollegiaalinen malli, pääministerin johtajuuteen perustuva malli ja ministerihallintomalli. Ministerihallintomalli piti pintansa, mutta pääministerimalli ja kollektiivinen johtamismalli täydensivät sitä. Koronakriisin johtaminen osoittaa, että kriisien uhatessa on ennakoitava toimivaltaisen ministeriön toimivallan ylittävää kriisin johtajuutta. Pääministeri Marin kykeni nousemaan kriisijohtajaksi siitä huolimatta, että lopullista ratkaisua kriisinjohtamismalleihin ei ole vielä löydetty eivätkä toimi- 
valtasuhteet ole olleet selkeät. Marinin kyky kriisijohtajana on saanut poikkeuksellista kansainvälistä mediahuomiota.

2000-luvun alun kiista kriisijohtamismallista on edelleen ratkaisematta. Vastuu vakavan, koko yhteiskuntaa uhkaavan kriisin johtamisesta ja sen kokoavasta koordinoinnista kuuluu pääministerille, jonka vastuut ovat laaja-alaisemmat kuin minkään ministeriön tai viranomaisen. Pääministerin johdolla hallituksen on määriteltävä kriisitilanteessa noudatettavat pelisäännöt ja vastuusuhteet. Uusi perustuslaki ja demokratian turvaaminen myös kriisitilanteessa edellyttävät valta- ja vastuusuhteiden määrittelyä lainsäädännössä. Kriisijohtamisen valta- ja johtosuhteista ei voida ryhtyä keskustelemaan vasta kriisin sytyttyä. Tällä hetkellä pääministerin valtuudet siviilikriisijohtamisessa ovat puutteelliset. Pääministerin on käytävä pelisäännöistä neuvonpitoa hallituksen sisällä ministerien kesken. Hallituksen johtajana pääministerin on osoitettava kriisitilanteessa selkeätä kokonaisjohtajuutta. Kriisissä ei ole varaa reviirikiistoihin. Johtajuus perustuu hallituksen toimintaan eduskunnan luottamuksen varassa. Koronakriisin selvittyä valtioneuvoston on täsmennettävä kriisijohtamismallia vahvemmin valtioneuvostotasoisen johtamisen suuntaan.

\section{LÄHTEET}

Asetus valtioneuvoston kansliasta 459/2003. https://www.finlex.fi/fi/laki/alkup/2003/20030459. Viitattu 1.3.2021.

Alter, Rolf. 2019. Valtioneuvoston ydin Suomessa - miten valmistautua paremmin tulevaisuuteen. https:// www.sitra.fi/julkaisut/valtioneuvoston-ydin-suomessa/. Viitattu 14.1.2021.

Blom, Anders. 2018. Veljeskunta - lobbaus Suomen politttisessa järjestelmässä. Helsinki: Gummerus.

Bouckaert, Geert, Ormond, Derry ja Peters, Guy. 2010. A Potential Agenda for Finland. Tutkimusraportteja 8/2000. Helsinki: Valtiovarainministeriö.

Buure-Hägglund, Kaarina. 2002. Suomen kriisilainsäädäntö. Helsinki: WSOY lakitieto.

Deloitte. 2021. Selvitys koronakriisin aikana toteutetun valtioneuvoston kriisijohtamisen ja valmiuslain käyttöönoton kokemuksista. Valtioneuvoston selvityksiä 2021:1. https://julkaisut.valtioneuvosto.fi/bitstream/ handle/10024/162677/2021_1_VN_Selvitys.pdf?sequence=1jaisAllowed=y. Viitattu 27.1.2021.

Forsberg, Tuomas. 2001. One foreign policy or two. Finland's new constitution and European policies of Tarja Halonen and Paavo Lipponen. Teoksessa Hanna Ojanen (toim.), Northern Dimensions. Fuel for the EU? Helsinki: Ulkopoliittinen instituutti.

Forsberg, Tuomas, Pursiainen, Christer, Lintonen, Raimo ja Visuri, Pekka (toim). 2003. Suomi ja kriisit. Vaaran vuosista terrori-iskuihin. Helsinki: Gaudeamus.

Haapala, Timo. 2020a. Kommentti: Tarvitaanko pääministerin kansliaan Suomen ykkösvoimien "teräsnyrkki” johtamaan koronakriisiä? Ilta-Sanomat 28.3.2020.

Haapala, Timo. 2020b. Kaikki ei oikeasti mennyt niin kuin julkisuuteen on annettu ymmärtää - IS paljastaa, miksi koronakriisi pääsi yllättämään Suomen. Ilta-Sanomat 27.3.2020.

Hallberg, Pekka, Martikainen, Tuomo, Nousiainen, Jaakko ja Tiikkanen, Päivi. 2009. Presidentin valta. Hallitsijanvallan ja parlamentarismin välinen jännite Suomessa 1919-2009. Helsinki: Werner Söderström Osakeyhtiö. 
HE 261/2016 vp. Hallituksen esitys eduskunnalle laiksi valtioneuvoston tilannekeskuksesta. 2016 vp. AK. Hellenberg, Timo, Talvitie, Heikki, Visuri, Pekka ja Volanen, Risto. 2011. Myrskyn silmässä. Suomi ja uudet kriisit. Jyväskylä: WSOYpro.

Jyränki, Antero. 2000. Uusi perustuslakimme. Turku: Iura nova.

Karjalainen, Elina. 2020. Hallitus perustaa uuden koronan operaatiokeskuksen - Marin: "Tieto ei ole kulkenut sillä tavalla kuin olisi pitänyt”. Helsingin Sanomat 4.4.2020.

Karvonen, Lauri, Paloheimo, Heikki ja Raunio, Tapio. 2016. Introduction. Finland 1970-2015. A Transformed Political Landscape. Teoksessa Lauri Karvonen, Heikki Paloheimo ja Tapio Raunio (toim.), The changing balance of political power in Finland. Stockholm: Santérus Academic Press, 9-30.

Kivelä, Juhani. 2010. Valtiokonsernin talousohjauksen tila - tuki vai taakka? Tampere: Tampereen yliopisto.

Kivelä, Juhani. 2016. Hiljainen hälytys. Yhteiskunnan häiriötilanteiden hallinnan tila vuosina 2012-2014. Helsinki: Väittelijä.

Marin, Sanna. 29.3.2020. Twitter-viestit. https://twitter.com/MarinSanna/status/1244271823807811585; https://twitter.com/MarinSanna/status/1244271827503001600; https://twitter.com/MarinSanna/status/1244271829633638403. Viitattu 17.6.2020.

Marin, Sanna. 30.3.2020. Pääministerin vastaus tasavallan presidentin kirjeeseen 26.3.2020. Valtioneuvoston viestintäosasto 30.3.2020. https://valtioneuvosto.fi/artikkeli/-/asset_publisher/10616/paaministerin-vastaus-tasavallan-presidentin-kirjeeseen-26-3-2020. Viitattu 20.12.2020.

Marin, Sanna. 29.4.2020. Pääministerin ilmoitus koronakriisin hoidosta. Pääministerin ilmoitus 292/2020. Valtioneuvoston viestintäosasto. https:/valtioneuvosto.fi/-/10616/paaministerin-ilmoituskoronakriisin-hoidosta. Viitattu 20.12.2020.

Murto, Eero. 1994. Pääministeri. Suomen pääministerin rooli 1917-1993. Helsinki: Painatuskeskus.

Myllymäki, Arvo. 2010. Suomen pääministeri. Presidentin varjosta hallitusvallasta käyttäjäksi. Helsinki: Talentum.

Mörttinen, Matti. 2021. Valtioneuvoston ydin kriisitilanteessa. Covid-19-pandemian paineet suomalaiselle päätöksenteolle. https://www.sitra.fi/julkaisut/valtioneuvoston-ydin-kriisitilanteessa/. Viitattu 14.1.2021.

Niinistö, Sauli. 2020. Tasavallan presidentin viesti pääministerille 26.3.2020. https://www.presidentti.fi/ uutinen/tasavallan-presidentin-kirje-paaministerille-26-3-2020/. Viitattu 20.12.2020.

Nousiainen, Jaakko. 1999. Hallintoa vai politiikkaa. Valtioneuvosto perinteen ja uudenaikaistumisvaateen ristikkäispaineessa. Lakimies 6-7/1999, 1102-1111.

Nurmi, Lauri ja Ristimäki, Juhani. 2020. IL paljastaa: Niinistö esitti turvallisuusneuvostoa - pääministeri Marin kaatoi valtiosäännön vastaisena. Iltalehti 28.3.2020.

Onnettomuustutkintakeskus. 2004. Aasian luonnonkatastrofi 26.12.2004. Tutkintaselostus A 2/2004 Y. https://turvallisuustutkinta.fi/material/attachments/otkes/tutkintaselostukset/fi/muutonnettomuudet/2004/a22004y_tutkintaselostus/a22004y_tutkintaselostus.pdf. Viitattu 20.12.2020.

Paloheimo, Heikki. 2001. Divided government in Finland: From a semi-presidential to a parliamentary democracy. Teoksessa Robert Elgie (toim.), Divided government in comparative perspective. Oxford: Oxford University Press, 86-105.

Paloheimo, Heikki. 2003. The Rising Power of the Prime Minister in Finland. Scandinavian Political Studies 26:3, 219-243. https://doi.org/0.1111/1467-9477.00086

Paloheimo, Heikki. 2005. Finland: let the force be with the leader-but who is the leader? Teoksessa. Thomas Poguntke ja Paul Webb (toim.), The presidentialization of politics. A comparative study of 
modern democracies. Oxford: Oxford University Press, 247-268.

https://doi.org/10.1093/0199252017.001.0001

Paloheimo, Heikki. 2016. The changing balance of power between president and cabinet. Teoksessa Lauri Karvonen, Heikki Paloheimo ja Tapio Raunio (toim.), The changing balance of political power in Finland. Tukholma: Santérus Academic Press, 57-90.

Raunio, Tapio. 2012. Semi-presidentialism and European integration: lessons from Finland for constitutional design. Journal of European Public Policy 19:4, 567-584.

https://doi.org/10.1080/13501763.2011.614139

Raunio, Tapio. 2016. The Effects of EU and Internationalization on the National Division of Power. Teoksessa Lauri Karvonen, Heikki Paloheimo ja Tapio Raunio (toim.), The changing balance of political power in Finland. Tukholma: Santérus Academic Press, 209-244.

Raunio, Tapio ja Wiberg, Matti. 2001. Parliamentarizing foreign policy decision-making Finland in the European Union. Cooperation and conflict 36:1, 61-86. https://doi.org/10.1177/00108360121962263

Raunio, Tapio ja Wiberg, Matti. 2003. Finland: Polarized Pluralism in the Shadow of a Strong President. Teoksessa Kaare Strøm, Wolfgang C. Müller ja Torbjörn Bergman (toim), Delegation and accountability in parliamentary democracies. Oxford: Oxford University Press, 301-324. https://doi.org/10.1093/019829784X.003.0008

Saari, Rauno. 2012. Pääministerille ja valtioneuvoston jäsenille suunnattu tilannekuvatoiminta. Helsinki: Valtioneuvoston kanslia.

Sosiaali- ja terveysministeriö, STM. 2020. Sosiaali- ja terveysministeriö on asettanut kansanterveysuhkaan varautumista koordinoivan ryhmän. STM:n asettamispäätös 13.2.2020. https://valtioneuvosto.fi/-/1271139/sosiaali-ja-terveysministerio-on-asettanut-kansanterveysuhkaan-varautumistakoordinoivan-ryhman. Viitattu 28.2.2021.

Valtioneuvoston asetus turvallisuuskomiteasta. 77/2013. https://www.finlex.fi/fi/laki/alkup/2013/20130077. Viitattu 28.2.2021.

Valtioneuvoston asetus valtioneuvoston kansliasta 459/2003. https://www.finlex.fi/fi/laki/alkup/2003/ 20030459. Viitattu 28.2.2021.

Valtioneuvoston asetus valtioneuvoston kansliasta (393/2007). https://www.finlex.fi/fi/laki/ajantasa/ 2007/20070393. Viitattu 28.2.2021.

Valtioneuvoston kanslia. 2010. Varautuminen ja kokonaisturvallisuus 2010. Valtioneuvoston kanslian julkaisusarja 21/2010. Helsinki. https://vnk.fi/documents/10616/622962/J2110_Varautuminen+ja+kokonaisturvallisuus.pdf/da689ade-30ad-4c1e-8221-90ecd62c4cad?version=1.0. Viitattu 20.12.2020.

Valtioneuvoston kanslia. 2015. Valtionneuvoston kanslian asetus valtioneuvoston kanslian työjärjestyksestä 162/2015. https://www.finlex.fi/fi/laki/ajantasa/2015/20150162. Viitattu 22.2.2021.

Valtioneuvoston periaatepäätös. 2003. Yhteiskunnan elintärkeiden toimintojen turvaamisen strategia 2003. https://www.defmin.fi/files/248/2515_1687_Yhteiskunnan_elintArkeiden_toimintojen_turvaamisen_ strategia_1_.pdf. Viitattu 20.12.2020.

Valtioneuvoston periaatepäätös. 2006. Yhteiskunnan elintärkeiden toimintojen turvaamisen strategia 2006. Helsinki: Puolustusministeriö. https://www.defmin.fi/files/815/YETT_2006.pdf. Viitattu 20.12.20

Valtioneuvoston periaatepäätös. 2010. Yhteiskunnan turvallisuusstrategia 2010. https://www.defmin.fi/ files/1696/Yhteiskunnan_turvallisuusstrategia_2010.pdf. Viitattu 20.12.2020.

Valtioneuvoston periaatepäätös. 2017. Yhteiskunnan turvallisuusstrategia 2017. https://turvallisuuskomitea.fi/wp-content/uploads/2018/02/YTS_2017_suomi.pdf. Viitattu 20.12.2020. 
Valtioneuvoston periaatepäätös. 2012. Valtioneuvoston periaatepäätös kokonaisturvallisuudesta. https:// www.defmin.fi/files/3023/Periaatepaatos_kokonaisturvallisuudesta_2012_fi.pdf. Viitattu 20.12.2020.

Valtioneuvoston viestintäosasto. 2020. Hallitus sai laajan katsauksen koronavirustilanteesta ja päätti lisäkoordinaatiosta. Tiedote 27.2.2020. https://valtioneuvosto.fi/-/10616/hallitus-sai-laajan-katsauksen-koronavirustilanteesta-ja-paatti-lisakoordinaatiosta. Viitattu 20.12.2020.

Valtiovarainministeriö. 2017. Valtioneuvoston kehittämistyöryhmän selvitys. Yhtenäinen valtioneuvosto syntyy yhteistyöllä ja yhtenäisillä toimintatavoilla. Valtiovarainministeriön julkaisu 15/2017. https:// valtioneuvosto.fi/documents/10623/3779937/Valtioneuvoston+kehitt\%C3\%A4misty\%C3\%B6ryhm \%C3\%A4n+selvitys/a319951b-c39d-4b24-9024-8018927ad466/Valtioneuvoston+kehitt\%C3\%A4mi sty\%C3\%B6ryhm\%C3\%A4n+selvitys.pdf. Viitattu 6.10.2020.

Vanhanen, Matti. 2020. Presidentti ja hallitus selvittelevät työnjakoaan. Eduskunnan puhemies Matti Vanhanen Yleisradion Ykkösaamussa 1.4.2020. Viitattu 2.4.2020.

Vesala, Hanna. 2020a. Pääministeri Marin IS:n haastattelussa presidentin roolista valmiuslaeissa: "Minua ei ole kukaan puskenut mihinkään suuntaan". Ilta-Sanomat 21.3.2020.

Vesala, Hanna. 2020b. IS:n tiedot: Presidentti lähetti hallitukselle nyrkkiryhmästä kirjeen - kohteliaassa vastauksessa idealle ei nähty tarvetta. Ilta-Sanomat 28.3.2020.

Virtanen, Petri, Uusikylä, Petri, Jalava, Janne, Tiihonen, Seppo, Laitinen, Lasse ja Noro, Kirsi. 2016. Valtioneuvoston yhtenäisyys - kansainvälinen vertaileva tutkimus. Valtioneuvoston selvitys- ja tutkimustoiminnan julkaisusarja 49/2016. https://vnk.fi/julkaisu?pubid=14502. Viitattu 20.12.2020.

Visuri, Pekka. 2003. Miten kriisinhallintaa pitäisi kehittää? Teoksessa Thomas Forsberg, Christer Pursiainen, Raimo Lintonen ja Pekka Visuri (toim.), Suomi ja kriisit. Vaaran vuosista terrori-iskuihin. Helsinki: Gaudeamus, 315-334.

Volanen, Risto. 2007. Siviilikriisien johtaminen demokraattisessa oikeusvaltiossa. Teoksessa Paula Tiihonen ja Risto Harisalo (toim.). Monen monta demokratiaa. Kauko Sipposen juhlaseminaari eduskunnassa 25.4.2007. Helsinki: Eduskunta. https://www.eduskunta.fi/FI/naineduskuntatoimii/ julkaisut/Documents/tuvj_3+2007.pdf. Viitattu 1.3.2021.29-37.

Volanen, Risto. 2011. Tsunami 2004: "Khao Lakissa kaikki hyvin". Teoksessa Timo Hellenberg, Heikki Talvitie, Pekka Visuri ja Risto Volanen (toim.), Myrskyn silmässä - Suomi ja uudet kriisit. Jyväskylä: WSOYpro Oy, 83-98.

Volanen, Risto. 2016. Pääministeri ulko- ja turvallisuuspoliittisena päättäjänä. Teoksessa Kimmo Pulkkinen, Hannu Mäntyvaara ja Risto Veltheim (toim.), Isänmaan airuet. Helsinki: Edita, 463-486.

\title{
KIRJOITTAJATIEDOT
}

\author{
SEPPO TIIHONEN \\ VTT, FM, dosentti \\ Yleinen valtio-oppi \\ Valtiotieteellinen tiedekunta \\ Helsingin yliopisto \\ tiihsepe@gmail.com
}

